\title{
Discards from Deep-water Bottom Trawling in the Eastern-Central Mediterranean Sea and Effects of Mesh Size Changes
}

\author{
G. D'Onghia, R. Carlucci, P. Maiorano, and M. Panza \\ Department of Zoology, University of Bari \\ Via Orabona, 4 - 70125 Bari, Italy
}

\begin{abstract}
Data on discards were collected during deep-water bottom seasonal trawling surveys targetting red shrimps (Aristeus antennatus and Aristaeomorpha foliacea) in the Ionian Sea (Eastern-Central Mediterranean). The performance of 3 codends, with stretched mesh sizes of 40, 50 and $60 \mathrm{~mm}$, was tested. A cover with a stretched mesh of $20 \mathrm{~mm}$ was employed on each codend.
\end{abstract}

The discarded catch constituted an important fraction of the total catch (20-50\%). This was almost exclusively due to unwanted fish species, while discards of the target species and other commercial species were negligible. Discard rates increased with total catch and depth.

No substantial differences were seen in the overall performance of the codends used. Differences were only detected in the biomass of the escaped fraction of the catch (both marketable and discards) and in the size selectivity. The $40 \mathrm{~mm}$ mesh size was not selective in Aristeus antennatus. Larger mesh size codend $(50$ and $60 \mathrm{~mm})$ allowed a higher number of small specimens to escape. The $50 \%$ retention sizes increased according to the mesh size in all examined species.

Key words: catch, discards, Mediterrranean Sea, mesh size selectivity

\section{Introduction}

According to Alverson et al. (1994) the "discarded catch" is the portion of the catch returned to the sea for economic, legal or personal reasons. Generally, the composition of the discarded catch depends on a great number of variables, which include season, gear and fishing method, depth and fishing grounds exploited, duration of the trip and hauls and occurrence of juveniles (Alverson et al., 1994).

Despite the great importance of discarding within the multispecies Mediterranean bottom trawling fisheries, there is only limited information concerning the amount, composition and factors affecting the discards (Stergiou et al., 1997 and 1998; Carbonell et al., 1998; Moranta et al., 2000; Machias et al., 2001; Ragonese et al., 2001). These studies generally suggest that "discards" from trawl fisheries are generally due to unwanted species (without commercial value), by-catch species (of low commercial value) and undersized specimens of species with higher commercial value.

In the Ionian Sea (Eastern-Central Mediterranean), the deepwater decapod crustacean fishery targets primarily red shrimps Aristeus antennatus and Aristaeomorpha foliacea. This fishery, along the Calabrian coasts, includes several bycatch species. Some of them, such as Merluccius merluccius, Nephrops norvegicus, Parapenaeus longirostris, Helicolenus dactylopterus and Lophius budegassa, are valuable species but many others, such as Phycis blennoides, Micromesistius poutassou, Lepidorhombus boscii, Plesionika martia, Eledone cirrhosa, are of low commercial value. Many species of no commercial value are often associated with the catch and always discarded (D'Onghia et al., 1997; Tursi et al., 1998). Although deepwater decapod crustaceans have long been intensively exploited in the Ionian Sea, scientific information on discards determined during fishing is only available in grey literature and the knowledge on the effects of the mesh size changes is very scanty (D'Onghia et al., 1998a).

The aim of this paper is to provide information on discards from the deep-water trawling in the Ionian Sea, pointing out the effects of the mesh size changes both on the amount of discards and in terms of 50\% retention length for some of the most abundant species in the study area. Full details of the selectivity experiment will be published in a separate paper. 


\section{Materials and Methods}

Data were collected during 8 seasonal trawl surveys carried out in the Ionian Sea (Fig. 1) from April 1996 to March 1998. A stratified sampling design was adopted in the depth range from 250 to $750 \mathrm{~m}$, where trawl fishing on deepwater red shrimps occurs. 12 hauls of 3-hour duration were carried out from dawn to dusk during each survey, emulating commercial trawling in the area. The locations of the tows were generally the same for each survey.

A commercial 75 tons (GT) motor powered vessel (360 hp), equipped with a nylon otter trawl net, was hired. The performance of 3 codends, with diamond stretched mesh sizes (sMS) of 40, 50 and $60 \mathrm{~mm}$, was tested. A cover with a sMS of $20 \mathrm{~mm}$ was employed on each codend. In order to avoid the masking of the codend meshes, the cover net was wider and longer than the test codend, and three arrays of plastic floats were attached to the top to prevent it from collapsing. The $40 \mathrm{~mm}$ sMS codend, which is the Italian legal mesh size, was used in all the surveys, while the 60 and $50 \mathrm{~mm}$ sMS codends were used in the first and in the last four surveys, respectively. A diagram of the net is shown in Fig. 2. The horizontal and vertical net opening, measured by means of the SCANMAR acoustic system, depended on various factors (depth, warp length, towing speed, etc.) and ranged respectively from $21.5 \mathrm{~m}$ to $24 \mathrm{~m}$ and from $0.9 \mathrm{~m}$ to 1 $\mathrm{m}$ (Fiorentini et al., 1994). The vessel speed, measured using GPS, was maintained at 2.5-3.0 knots. Basic information on each haul is reported in Table 1.

The "discard rate" (DR) considered as the proportion of the total catch, which is discarded (Alverson et al., 1994), was computed for the total catch for each survey and codend. The G-test (Sokal and Rohlf, 1969) was used to evaluate significant changes in the discarded and marketable catch by survey and mesh size. The relationship between discard rate and total catch and between discard rate and depth was determined for the $40 \mathrm{~mm}$ sMS codend by means of linear regression. The relationships

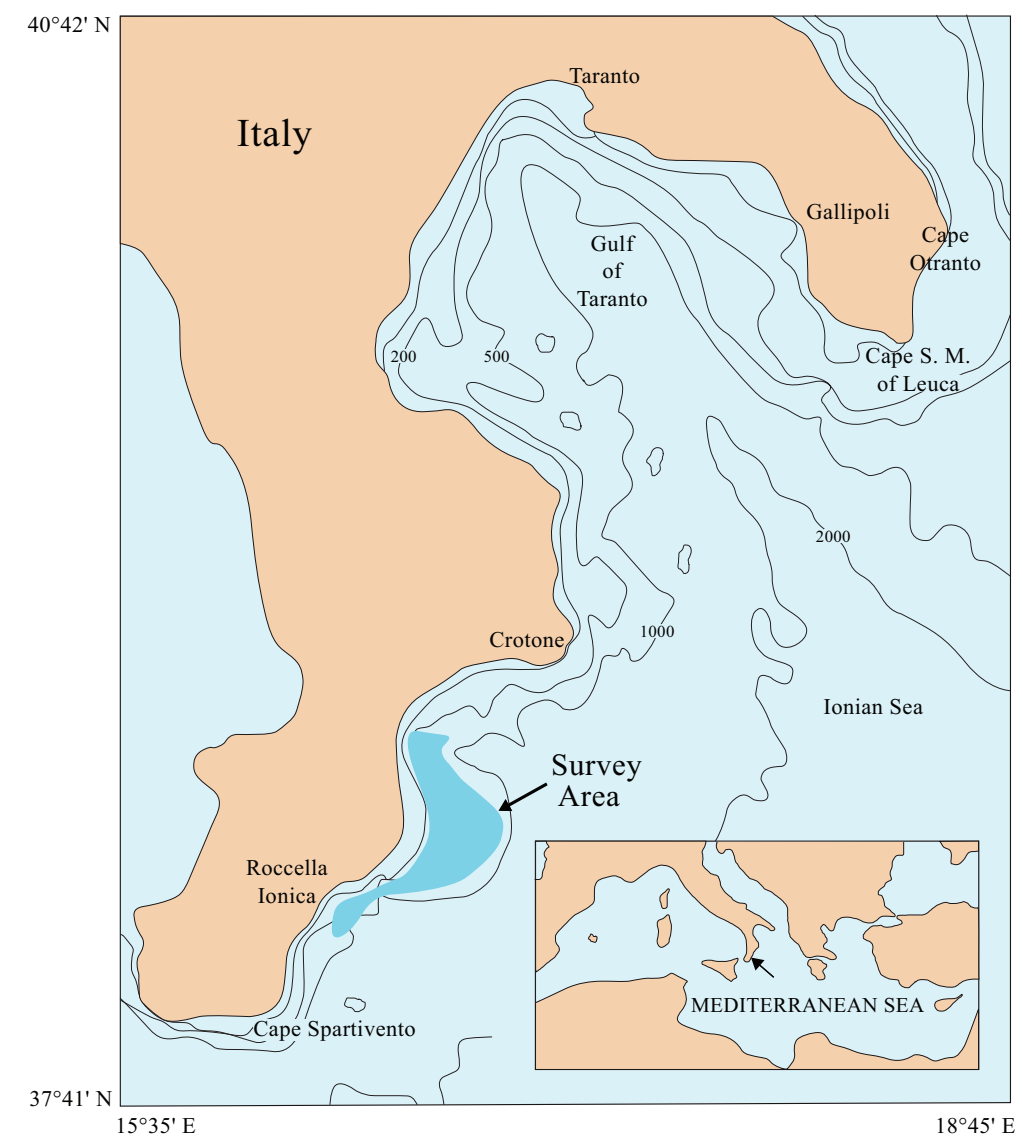

Fig. 1. Map of the Ionian Sea (eastern-central Mediteranean) with indication of the area investigated from April 1996 to March 1998. 


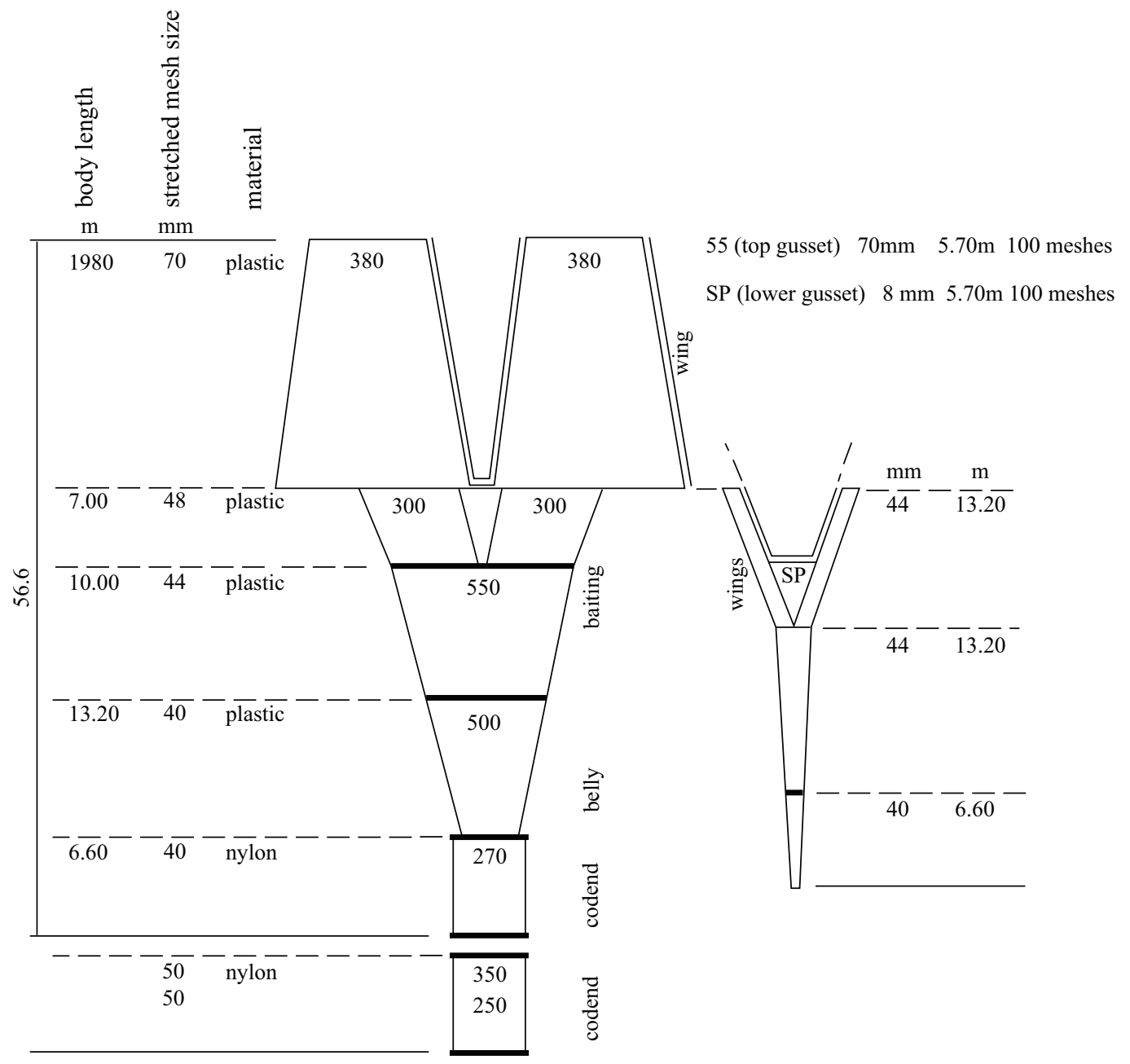

Fig. 2. Diagram of the trawl net used in the Ionian Sea surveys from April 1996 to March 1998.

between total catch, discarded catch, marketable catch that passed into the cover and the mesh size codend were also analysed.

Length-frequency distributions for each codend used were calculated for the following species: a) Aristeus antennatus (target commercial species); b) Helicolenus dactylopterus, Phycis blennoides, Micromesistius poutassou (bycatch species); c) Caelorhynchus caelorhynchus (unwanted species). According to the covered codend method adopted during each haul (Pope et al., 1975), the retention sizes at $50 \%\left(L_{50}\right)$ were computed for these species using the logistic model as described in Sparre and Venema (1998). The fit of data and the relative significance for each sMS codend was carried out using the maximum likelihood function (Wileman et al., 1996).

\section{Results}

\section{$40 \mathrm{~mm}$ mesh size codend}

During this study, the average discard rate with $40 \mathrm{~mm}$ sMS codend ranged from 0.23 (April 1996) to 0.45 (December 1997) within an average total catch per hour between $11.24 \mathrm{~kg} / \mathrm{h}$ (July 1996) and 23.32 kg/h (October 1996) (Fig. 3). The highest average DR values were seen during July 1996 and December 1997, however the changes in the rates of the discarded and marketable catch (both target and bycatch species) throughout the 8 surveys were not statistically significant (G-test $=4.36, p>0.05$ ).

The relationships between DR and total catch per hour and between DR and depth were both positive (Fig. 4): 
TABLE 1. List of the hauls, with indication of the stretched mesh size, date, duration, starting hour, depth, wire length, towing speed, total catch $(\mathrm{kg})$ and total catch per hour $(\mathrm{kg} / \mathrm{h})$ carried out in the Ionian Sea from April 1996 to March 1998.

\begin{tabular}{|c|c|c|c|c|c|c|c|c|c|c|}
\hline $\begin{array}{c}\text { Stretched } \\
\text { mesh size } \\
(\mathrm{mm})\end{array}$ & Survey & Haul & Date & $\begin{array}{l}\text { Duration } \\
\text { (minutes) }\end{array}$ & $\begin{array}{c}\text { Starting } \\
\text { hour }\end{array}$ & $\begin{array}{c}\text { Depth } \\
\text { (m) }\end{array}$ & \begin{tabular}{|c|}
$\begin{array}{c}\text { Wire length } \\
(\mathrm{m})\end{array}$ \\
\end{tabular} & $\begin{array}{c}\text { Towing } \\
\text { speed }\end{array}$ & \begin{tabular}{|c|} 
Total catch \\
$\mathrm{kg}$
\end{tabular} & $\begin{array}{c}\text { Total catch } \\
\text { per hour } \\
(\mathrm{kg} / \mathrm{h})\end{array}$ \\
\hline 40 & $\mathrm{I}$ & 1 & 4/16/1996 & 165 & 06.15 & 324 & 1050 & 2.5 & 57.88 & 21.05 \\
\hline 40 & I & 2 & 4/16/1996 & 180 & 09.50 & 478 & 1500 & 2.5 & 59.92 & 19.98 \\
\hline 40 & I & 3 & 4/16/1996 & 180 & 13.35 & 399 & 1300 & 2.5 & 63.05 & 21.02 \\
\hline 40 & I & 4 & $4 / 17 / 1996$ & 180 & 06.05 & 579 & 1650 & 2.5 & 26.19 & 8.73 \\
\hline 40 & I & 5 & 4/17/1996 & 180 & 09.55 & 530 & 1550 & 2.5 & 26.63 & 8.88 \\
\hline 40 & I & 6 & $4 / 17 / 1996$ & 140 & 13.50 & 643 & 1800 & 2.5 & 19.67 & 8.44 \\
\hline 40 & II & 1 & $7 / 21 / 1996$ & 180 & 06.50 & 312 & 1050 & 2.6 & 11.17 & 3.72 \\
\hline 40 & II & 2 & $7 / 21 / 1996$ & 180 & 10.30 & 405 & 1350 & 2.4 & 35.7 & 11.9 \\
\hline 40 & II & 3 & $7 / 21 / 1996$ & 180 & 15.00 & 509 & 1600 & 2.4 & 19.41 & 6.47 \\
\hline 40 & II & 4 & $7 / 22 / 1996$ & 180 & 05.10 & 461 & 1500 & 2.4 & 42.33 & 14.11 \\
\hline 40 & II & 5 & $7 / 22 / 1996$ & 180 & 09.25 & 581 & 1700 & 2.4 & 46.56 & 15.52 \\
\hline 40 & II & 6 & 7/22/1996 & 175 & 13.10 & 676 & 1800 & 2.4 & 45.86 & 15.73 \\
\hline 40 & III & 1 & $10 / 23 / 1996$ & 190 & 06.35 & 321 & 1100 & 2.5 & 82.9 & 26.18 \\
\hline 40 & III & 2 & $10 / 23 / 1996$ & 160 & 10.30 & 380 & 1250 & 2.5 & 88.79 & 33.29 \\
\hline 40 & III & 3 & $10 / 23 / 1996$ & 190 & 14.00 & 470 & 1500 & 2.6 & 61.91 & 19.56 \\
\hline 40 & III & 4 & $10 / 24 / 1996$ & 165 & 08.20 & 520 & 1550 & 2.5 & 65.66 & 23.88 \\
\hline 40 & III & 5 & $10 / 24 / 1996$ & 172 & 12.15 & 660 & 1800 & 2.5 & 93.55 & 32.64 \\
\hline 40 & III & 6 & $10 / 24 / 1996$ & 140 & 16.10 & 601 & 1700 & 2.5 & 10.17 & 4.36 \\
\hline 40 & IV & 1 & $2 / 15 / 1997$ & 180 & 06.50 & 303 & 1050 & 2.6 & 65.42 & 21.81 \\
\hline 40 & IV & 2 & $2 / 15 / 1997$ & 190 & 10.35 & 387 & 1300 & 2.3 & 51.64 & 16.31 \\
\hline 40 & IV & 3 & $2 / 15 / 1997$ & 180 & 14.35 & 462 & 1450 & 2.5 & 24.76 & 8.26 \\
\hline 40 & IV & 4 & $2 / 26 / 1997$ & 185 & 06.15 & 662 & 1800 & 2.6 & 76.36 & 24.76 \\
\hline 40 & IV & 5 & $2 / 26 / 1997$ & 175 & 10.25 & 606 & 1700 & 2.5 & 52.77 & 18.1 \\
\hline 40 & IV & 6 & $2 / 26 / 1997$ & 180 & 14.25 & 545 & 1650 & 2.5 & 22.28 & 7.42 \\
\hline 40 & $\mathrm{~V}$ & 1 & $5 / 2 / 1997$ & 180 & 06.05 & 326 & 1050 & 2.6 & 46.53 & 15.51 \\
\hline 40 & $\mathrm{~V}$ & 2 & $5 / 2 / 1997$ & 180 & 09.45 & 379 & 1250 & 2.5 & 34.77 & 11.59 \\
\hline 40 & $\mathrm{~V}$ & 3 & $5 / 2 / 1997$ & 190 & 13.30 & 445 & 1450 & 2.6 & 26.35 & 8.33 \\
\hline 40 & $\mathrm{~V}$ & 4 & $5 / 3 / 1997$ & 180 & 06.15 & 658 & 1750 & 2.6 & 69.83 & 23.28 \\
\hline 40 & $\mathrm{~V}$ & 5 & $5 / 3 / 1997$ & 175 & 10.10 & 577 & 1700 & 2.6 & 12.22 & 4.19 \\
\hline 40 & $\mathrm{~V}$ & 6 & $5 / 3 / 1997$ & 175 & 14.00 & 509 & 1600 & 2.5 & 17.9 & 6.13 \\
\hline 40 & VI & 1 & 7/23/1997 & 180 & 06.05 & 320 & 1050 & 2.5 & 71.84 & 23.95 \\
\hline 40 & VI & 2 & $7 / 23 / 1997$ & 175 & 09.50 & 388 & 1250 & 2.6 & 16.81 & 5.76 \\
\hline 40 & VI & 3 & $7 / 23 / 1997$ & 195 & 13.45 & 454 & 1500 & 2.5 & 23.92 & 7.36 \\
\hline 40 & VI & 4 & $7 / 24 / 1997$ & 160 & 08.00 & 676 & 1800 & 2.5 & 125.66 & 47.13 \\
\hline 40 & VI & 5 & $7 / 24 / 1997$ & 175 & 12.00 & 606 & 1700 & 2.6 & 38.18 & 13.09 \\
\hline 40 & VI & 6 & $7 / 24 / 1997$ & 165 & 16.05 & 540 & 1600 & 2.5 & 19.4 & 7.05 \\
\hline 40 & VII & 1 & 12/10/1997 & 180 & 06.25 & 673 & 1800 & 2.3 & 54.85 & 18.29 \\
\hline \multirow[t]{2}{*}{40} & VII & 2 & $12 / 10 / 1997$ & 180 & 10.30 & 590 & 1700 & 2.7 & 16.77 & 5.59 \\
\hline & VII & 3 & $12 / 10 / 1997$ & 125 & 14.15 & 515 & 1600 & 2.7 & 19.02 & 9.13 \\
\hline
\end{tabular}


TABLE 1. (Continued). List of the hauls, with indication of the stretched mesh size, date, duration, starting hour, depth, wire length, towing speed, total catch $(\mathrm{kg})$ and total catch per hour $(\mathrm{kg} / \mathrm{h})$ carried out in the Ionian Sea from April 1996 to March 1998.

\begin{tabular}{|c|c|c|c|c|c|c|c|c|c|c|}
\hline $\begin{array}{c}\text { Stretched mesh } \\
\text { size } \\
(\mathrm{mm}) \\
\end{array}$ & Survey & Haul & Date & $\begin{array}{l}\text { Duration } \\
\text { (minutes) }\end{array}$ & $\begin{array}{c}\text { Starting } \\
\text { hour }\end{array}$ & $\begin{array}{c}\text { Depth } \\
\text { (m) }\end{array}$ & $\begin{array}{c}\text { Wire length } \\
\text { (m) }\end{array}$ & $\begin{array}{c}\text { Towing } \\
\text { speed }\end{array}$ & $\begin{array}{c}\text { Total catch } \\
\text { kg }\end{array}$ & $\begin{array}{c}\text { Total catch } \\
\text { per hour } \\
(\mathrm{kg} / \mathrm{h})\end{array}$ \\
\hline 40 & VII & 10 & $12 / 13 / 1997$ & 150 & 06.25 & 462 & 1450 & 2.7 & 14.52 & 5.8 \\
\hline 40 & VII & 11 & $12 / 13 / 1997$ & 165 & 09.45 & 352 & 1250 & 2.5 & 22.28 & 8.1 \\
\hline 40 & VII & 12 & $12 / 13 / 1997$ & 148 & 13.15 & 243 & 850 & 2.8 & 74.37 & 30.15 \\
\hline 40 & VIII & 1 & $3 / 4 / 1998$ & 180 & 06.45 & 673 & 1850 & 2.5 & 65.13 & 21.71 \\
\hline 40 & VIII & 2 & $3 / 4 / 1998$ & 180 & 11.00 & 589 & 1700 & 2.5 & 46.78 & 15.6 \\
\hline 40 & VIII & 3 & $3 / 4 / 1998$ & 180 & 15.00 & 519 & 1600 & 2.5 & 44.72 & 14.9 \\
\hline 40 & VIII & 10 & $3 / 7 / 1998$ & 180 & 05.45 & 379 & 1250 & 2.5 & 16.69 & 5.56 \\
\hline 40 & VIII & 11 & $3 / 7 / 1998$ & 165 & 09.25 & 461 & 1500 & 2.5 & 26.49 & 9.63 \\
\hline 40 & VIII & 12 & $3 / 7 / 1998$ & 160 & 13.00 & 306 & 1050 & 2.5 & 28.66 & 10.75 \\
\hline 50 & $\mathrm{~V}$ & 7 & $5 / 4 / 1997$ & 185 & 06.05 & 660 & 1750 & 2.6 & 50.43 & 16.35 \\
\hline 50 & $\mathrm{~V}$ & 8 & $5 / 4 / 1997$ & 174 & 10.20 & 511 & 1650 & 2.5 & 18.49 & 6.38 \\
\hline 50 & $\mathrm{~V}$ & 9 & $5 / 4 / 1997$ & 180 & 15.40 & 568 & 1750 & 2.5 & 15.24 & 5.08 \\
\hline $\mathbf{5 0}$ & $\mathrm{V}$ & 10 & $5 / 5 / 1997$ & 170 & 05.45 & 315 & 1050 & 2.6 & 68.1 & 24.03 \\
\hline 50 & $\mathrm{~V}$ & 11 & $5 / 5 / 1997$ & 170 & 09.20 & 384 & 1300 & 2.5 & 21.3 & 7.53 \\
\hline $\mathbf{5 0}$ & $\mathrm{V}$ & 12 & $5 / 5 / 1997$ & 165 & 13.00 & 452 & 1450 & 2.5 & 28.49 & 10.36 \\
\hline 50 & VI & 7 & $7 / 25 / 1997$ & 170 & 05.40 & 305 & 1050 & 2.6 & 50.85 & 17.95 \\
\hline $\mathbf{5 0}$ & VI & 8 & $7 / 25 / 1997$ & 170 & 09.20 & 360 & 1250 & 2.5 & 22.77 & 8.04 \\
\hline 50 & VI & 9 & $7 / 25 / 1997$ & 175 & 13.05 & 465 & 1400 & 2.5 & 15.45 & 5.29 \\
\hline 50 & VI & 10 & $7 / 27 / 1997$ & 180 & 06.00 & 666 & 1800 & 2.5 & 44.77 & 14.92 \\
\hline 50 & VI & 11 & $7 / 27 / 1997$ & 140 & 10.10 & 602 & 1700 & 2.6 & 13.92 & 5.97 \\
\hline $\mathbf{5 0}$ & VI & 12 & $7 / 27 / 1997$ & 120 & 14.10 & 512 & 1550 & 2.7 & 22.92 & 11.47 \\
\hline 50 & VII & 4 & $12 / 11 / 1997$ & 180 & 06.30 & 659 & 1800 & 2.7 & 27.5 & 9.16 \\
\hline 50 & VII & 5 & $12 / 11 / 1997$ & 180 & 10.30 & 590 & 1700 & 2.7 & 17.75 & 5.91 \\
\hline 50 & VII & 6 & $12 / 11 / 1997$ & 160 & 14.20 & 519 & 1600 & 2.7 & 23.02 & 8.63 \\
\hline 50 & VII & 7 & $12 / 12 / 1997$ & 145 & 08.25 & 474 & 1450 & 2.7 & 31.54 & 13.05 \\
\hline 50 & VII & 8 & $12 / 12 / 1997$ & 175 & 11.35 & 387 & 1350 & 2.7 & 24.39 & 8.36 \\
\hline 50 & VII & 9 & $12 / 12 / 1997$ & 135 & 15.15 & 304 & 1000 & 2.8 & 29.15 & 12.95 \\
\hline 50 & VIII & 4 & $3 / 5 / 1998$ & 180 & 06.00 & 672 & 1850 & 2.5 & 56.09 & 18.7 \\
\hline 50 & VIII & 5 & $3 / 5 / 1998$ & 180 & 10.00 & 582 & 1700 & 2.5 & 70.04 & 23.34 \\
\hline 50 & VIII & 6 & $3 / 5 / 1998$ & 180 & 14.00 & 507 & 1600 & 2.5 & 21.76 & 7.25 \\
\hline 50 & VIII & 7 & $3 / 6 / 1998$ & 170 & 06.05 & 474 & 1500 & 2.5 & 16.06 & 5.67 \\
\hline 50 & VIII & 8 & $3 / 6 / 1998$ & 180 & 10.00 & 369 & 1300 & 2.5 & 9.59 & 3.2 \\
\hline 50 & VIII & 9 & $3 / 6 / 1998$ & 175 & 13.50 & 314 & 1100 & 2.5 & 40.31 & 13.83 \\
\hline 60 & I & 7 & 4/18/1996 & 180 & 06.10 & 399 & 1300 & 2.5 & 17.09 & 5.7 \\
\hline 60 & I & 8 & $4 / 18 / 1996$ & 165 & 10.05 & 486 & 1450 & 2.5 & 33.31 & 12.12 \\
\hline 60 & $\mathrm{I}$ & 9 & 4/18/1996 & 175 & 13.50 & 313 & 1050 & 2.5 & 26.54 & 9.09 \\
\hline 60 & I & 10 & $4 / 19 / 1996$ & 180 & 05.45 & 589 & 1700 & 2.6 & 17.23 & 5.74 \\
\hline 60 & $\mathrm{I}$ & 11 & $4 / 19 / 1996$ & 170 & 09.40 & 528 & 1600 & 2.6 & 31.98 & 11.29 \\
\hline 60 & $\mathrm{I}$ & 12 & 4/19/1996 & 150 & 13.25 & 670 & 1850 & 2.6 & 28.89 & 11.55 \\
\hline 60 & II & 7 & $7 / 23 / 1996$ & 185 & 06.00 & 313 & 1050 & 2.4 & 20.49 & 6.65 \\
\hline
\end{tabular}


TABLE 1. (Continued). List of the hauls, with indication of the stretched mesh size, date, duration, starting hour, depth, wire length, towing speed, total catch $(\mathrm{kg})$ and total catch per hour $(\mathrm{kg} / \mathrm{h})$ carried out in the Ionian Sea from April 1996 to March 1998.

\begin{tabular}{|c|c|c|c|c|c|c|c|c|c|c|}
\hline $\begin{array}{c}\text { Stretched mesh size } \\
(\mathbf{m m})\end{array}$ & Survey & Haul & Date & $\begin{array}{c}\text { Duration } \\
\text { (minutes) }\end{array}$ & $\begin{array}{c}\text { Starting } \\
\text { hour }\end{array}$ & $\begin{array}{c}\text { Depth } \\
\text { (m) }\end{array}$ & $\begin{array}{c}\text { Wire length } \\
(\mathbf{m})\end{array}$ & $\begin{array}{c}\text { Towing } \\
\text { speed }\end{array}$ & $\begin{array}{c}\text { Total catch } \\
\mathbf{k g}\end{array}$ & $\begin{array}{c}\text { Total catch } \\
\text { per hour } \\
\text { (kg/h) }\end{array}$ \\
\hline $\mathbf{6 0}$ & II & 8 & $7 / 23 / 1996$ & 185 & 10.35 & 478 & 1500 & 2.4 & 11.68 & 3.79 \\
\hline $\mathbf{6 0}$ & II & 9 & $7 / 23 / 1996$ & 170 & 14.40 & 400 & 1350 & 2.4 & 18.96 & 6.69 \\
\hline $\mathbf{6 0}$ & II & 10 & $7 / 24 / 1996$ & 175 & 05.50 & 511 & 1600 & 2.4 & 15.06 & 5.16 \\
\hline $\mathbf{6 0}$ & II & 11 & $7 / 24 / 1996$ & 180 & 09.40 & 573 & 1700 & 2.4 & 36.7 & 12.23 \\
\hline $\mathbf{6 0}$ & II & 12 & $7 / 24 / 1996$ & 180 & 13.40 & 655 & 1850 & 2.4 & 34.42 & 11.47 \\
\hline $\mathbf{6 0}$ & III & 7 & $10 / 25 / 1996$ & 180 & 06.45 & 664 & 1800 & 2.5 & 86.59 & 28.86 \\
\hline $\mathbf{6 0}$ & III & 8 & $10 / 25 / 1996$ & 180 & 11.00 & 586 & 1650 & 2.3 & 6.22 & 2.07 \\
\hline $\mathbf{6 0}$ & III & 9 & $10 / 25 / 1996$ & 180 & 15.00 & 515 & 1600 & 2.3 & 38.81 & 12.94 \\
\hline $\mathbf{6 0}$ & III & 10 & $10 / 26 / 1996$ & 175 & 06.35 & 452 & 1450 & 2.5 & 74.53 & 25.55 \\
\hline $\mathbf{6 0}$ & III & 12 & $10 / 26 / 1996$ & 175 & 14.05 & 326 & 1050 & 2.6 & 48.91 & 16.77 \\
\hline $\mathbf{6 0}$ & IV & 7 & $2 / 27 / 1997$ & 180 & 06.40 & 274 & 1050 & 2.6 & 21.81 & 7.27 \\
\hline $\mathbf{6 0}$ & IV & 8 & $3 / 4 / 1997$ & 180 & 06.35 & 669 & 1800 & 2.6 & 86.61 & 28.87 \\
\hline $\mathbf{6 0}$ & IV & 9 & $3 / 4 / 1997$ & 180 & 10.35 & 611 & 1700 & 2.5 & 35.96 & 11.98 \\
\hline $\mathbf{6 0}$ & IV & 10 & $3 / 4 / 1997$ & 180 & 14.25 & 532 & 1650 & 2.5 & 19.2 & 6.4 \\
\hline $\mathbf{6 0}$ & IV & 11 & $3 / 5 / 1997$ & 180 & 06.05 & 470 & 1450 & 2.6 & 23.62 & 7.88 \\
\hline $\mathbf{6 0}$ & IV & 12 & $3 / 5 / 1997$ & 150 & 12.15 & 397 & 1250 & 2.5 & 28.9 & 11.56 \\
\hline
\end{tabular}

$D R=0.1856+0.0093$ Total catch per hour; $r=0.35 ; n=48 ; p<0.01$

$D R=-0.3142+0.0013$ Depth $r=0.67 ; n=48 ; p<0.01$

Concerning the catch composition, 162 species were collected. Two of them (Aristeus antennatus and Aristaeomorpha foliacea) were target species, 34 were by-catch with variable commercial value and 126 were unwanted species. Discarded catch was mostly due to

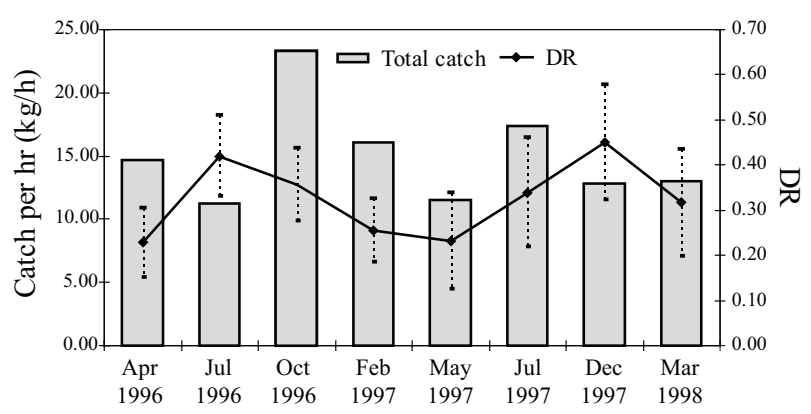

Fig. 3. Average total catch per hour $(\mathrm{kg} / \mathrm{h})$ and average discard rate (DR), with relative standard error, computed by survey for $40 \mathrm{~mm}$ mesh size codend. unwanted species $(99.25 \%$ on average), mainly represented by C. caelorhynchus, H. italicus, $N$. sclerorhynchus, H. mediterraneus, C. agassizi and G. melastomus. The contribution of bycatch species (both with high and low commercial value) to the discards was very low $(0.75 \%$ on average) (Fig. 5$)$. This latter contribution was mainly represented by small specimens of $H$. dactylopterus, P. blennoides and M. poutassou. The differences between these two discard fractions (unwanted and by-catch species) within the whole discarded catch between the surveys were not statistically significant (G-test $=0.46$, $p>0.05$ ).

Fish, crustaceans and cephalopods represented $90.8 \%, 6.4 \%$ and $2.8 \%$ of the discarded catch, respectively. In the marketable catch, the highest fraction on average comprised crustaceans $(66.9 \%)$, followed by fish (24.2\%) and cephalopods (8.9\%).

\section{Mesh size codend comparison}

The average DR for the $50 \mathrm{~mm}$ sMS codend ranged from 0.18 (July 1997) to 0.37 (December 1997) as part of an average total catch per hour between $10.61 \mathrm{~kg} / \mathrm{h}$ and $9.68 \mathrm{~kg} / \mathrm{h}$, respectively. The $60 \mathrm{~mm}$ 

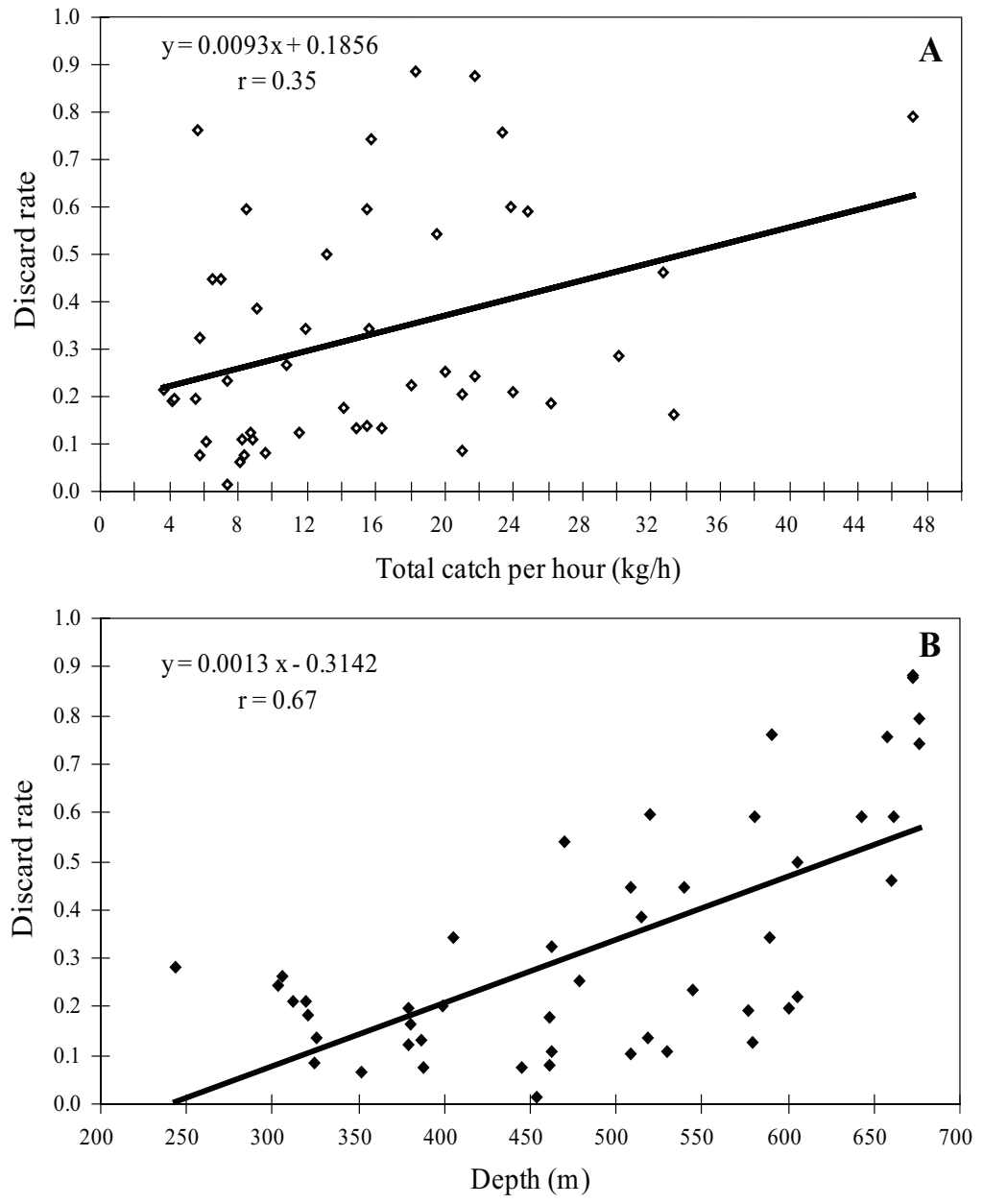

Fig. 4. Relationship between discard rate and total catch per hour (A) and discard rate and depth (B) computed for the hauls carried out with the $40 \mathrm{~mm}$ mesh size codend.

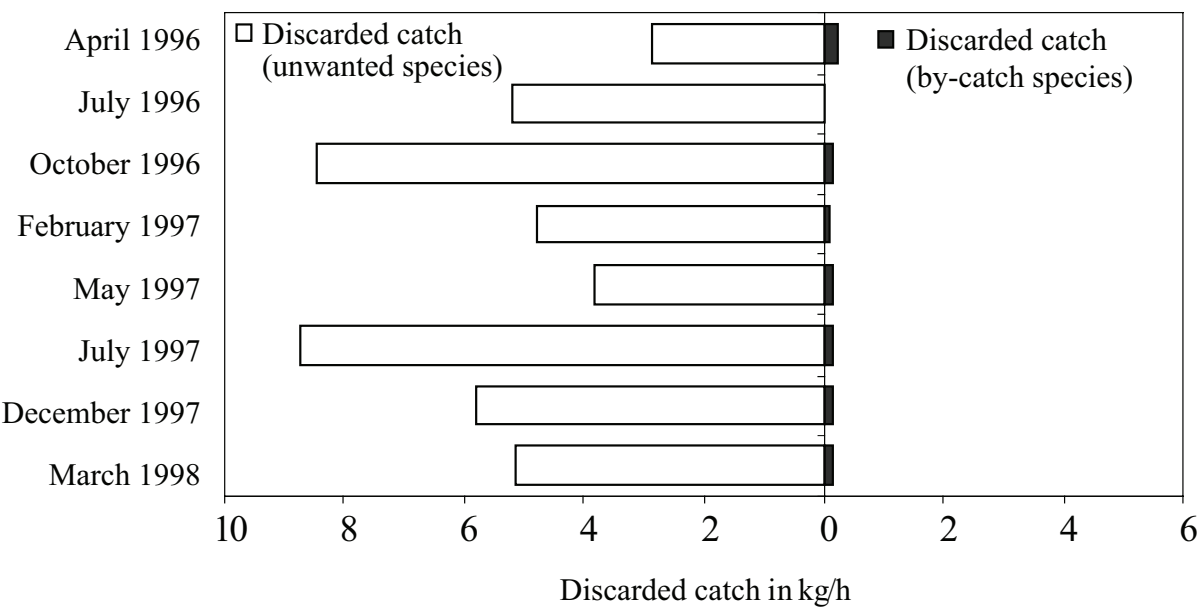

Fig. 5. Average discarded catch per hour, due to unwanted and by-catch species, computed for each survey carried out in the Ionian Sea with the $40 \mathrm{~mm}$ mesh size codend. 


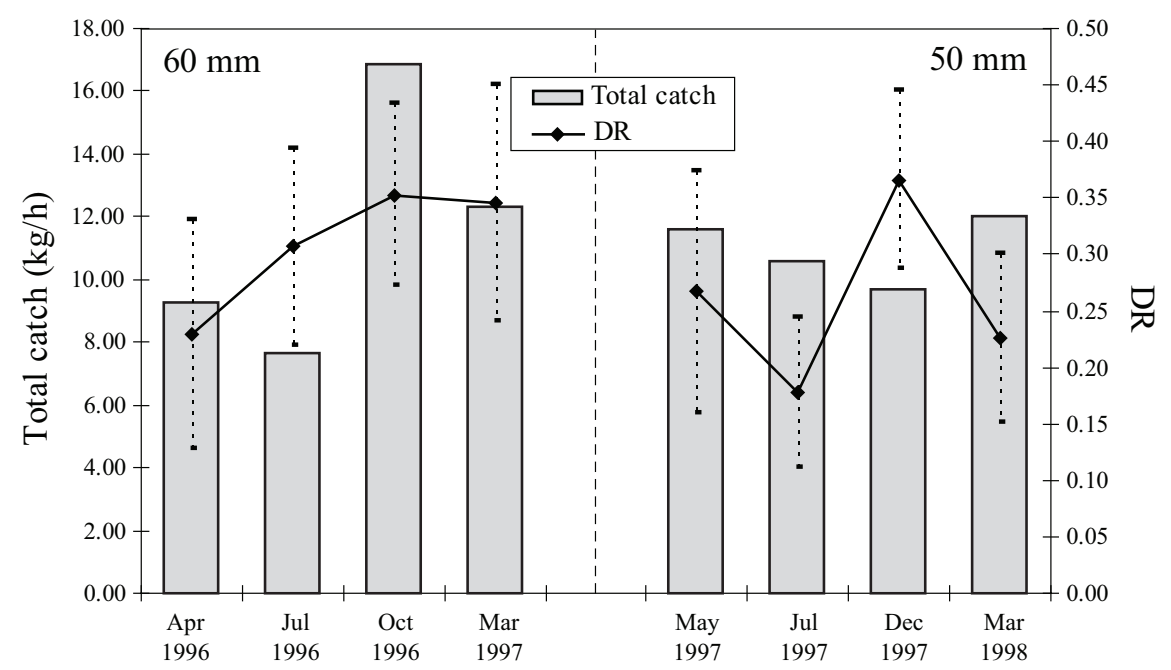

Fig. 6. Average total catch per hour $(\mathrm{kg} / \mathrm{h})$ and average discard rate (DR), with relative standard error, computed by survey for 60 and $50 \mathrm{~mm}$ mesh size codend.

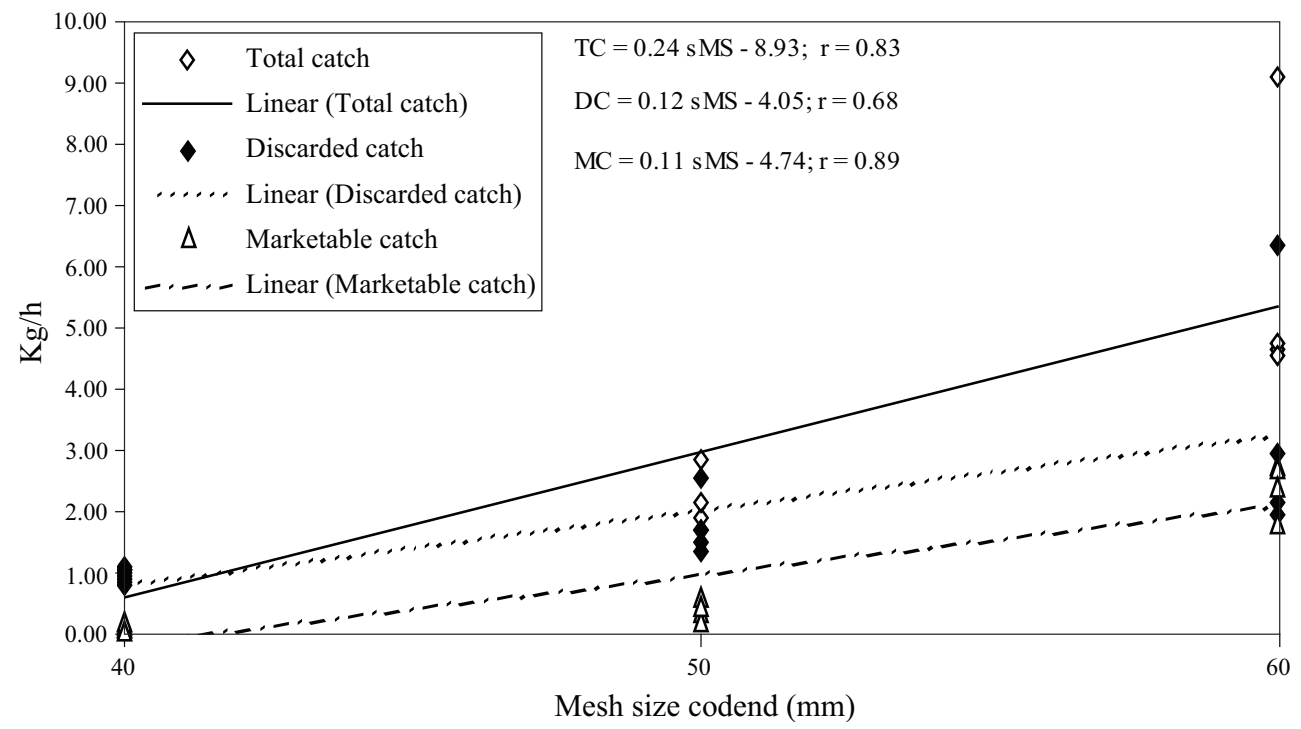

Fig. 7. Different relationships computed for total catch (TC), discarded catch (DC) and marketable catch (MC), in kg per hour retained in the cover in relation to stretched mesh size of codend.

sMS codend showed mean DR values between 0.23 (April 1996) and 0.35 (October 1996) within an average total catch per hour of $9.25 \mathrm{~kg} / \mathrm{h}$ and 16.87 $\mathrm{kg} / \mathrm{h}$, respectively (Fig. 6).

The changes in discarded and marketable catch (both target and by-catch species) with the three codends, considered for the pooled data were not statistically significant (G-test $=0.45, p>0.05)$. The relationship between the catch passing into the cover (total, marketable and discards) and the mesh size of the codend was positive (Fig. 7). Moreover, the changes of the discard fraction relative to the total catch in the cover with the different sMS codends were not significant (G-test $=0.12, p>0.05)$. In other words, the proportion between marketable and discards in the cover did not change with increasing mesh size in the codend. 
No substantial differences were found between the three codends with regard to the qualitative composition of discards and marketable components of the catch.

\section{Size distribution and selectivity parameters}

Concerning Aristeus antennatus, the individuals caught with the $40 \mathrm{~mm}$ sMS codend were almost fully retained. The fraction escaping into the cover increased according to the mesh size (Fig. 8). The retention sizes at $50 \%$ computed for the 50 and 60 mm sMS codends were $19.0 \pm 0.2$ and $25.4 \pm 0.2 \mathrm{~mm}$ carapace lengths respectively (Fig. 9). Only specimens crushed during hauling and sorting operations were discarded with all three codends.

Specimens of Helicolenus dactylopterus smaller than $100 \mathrm{~mm}$ total length (TL) were always discarded.
Their number retained in the codend decreased markedly with mesh size, thus reducing the discarded fraction (Fig. 10). The best fit of data in the selectivity curves was shown for the 40 and $50 \mathrm{~mm}$ mesh sizes, which provided comparable selectivity parameters (SR, SF) and $L_{50}$ values of $55.2 \pm 0.5 \mathrm{~mm} \mathrm{TL}$ and $74.6 \pm 1,1 \mathrm{~mm}$ TL, respectively (Fig. 11).

Individuals of Phycis blennoides smaller than 160 $\mathrm{mm}$ TL were always rejected. Larger specimens up to $240 \mathrm{~mm}$ TL specimens were retained or discarded according to their state of preservation. The discarded fraction in the codend decreased according to the mesh size while the percentage fraction of the specimens escaping into the cover increased (Fig. 12). The $50 \%$ retention sizes were $90.9 \pm 0.8 \mathrm{~mm}$ TL for the $40 \mathrm{~mm}$ sMS, $112.4 \pm 2.4 \mathrm{~mm}$ TL for $50 \mathrm{~mm}$ and $173.9 \pm 3.3 \mathrm{~mm}$ TL for $60 \mathrm{~mm}$ (Fig. 13).

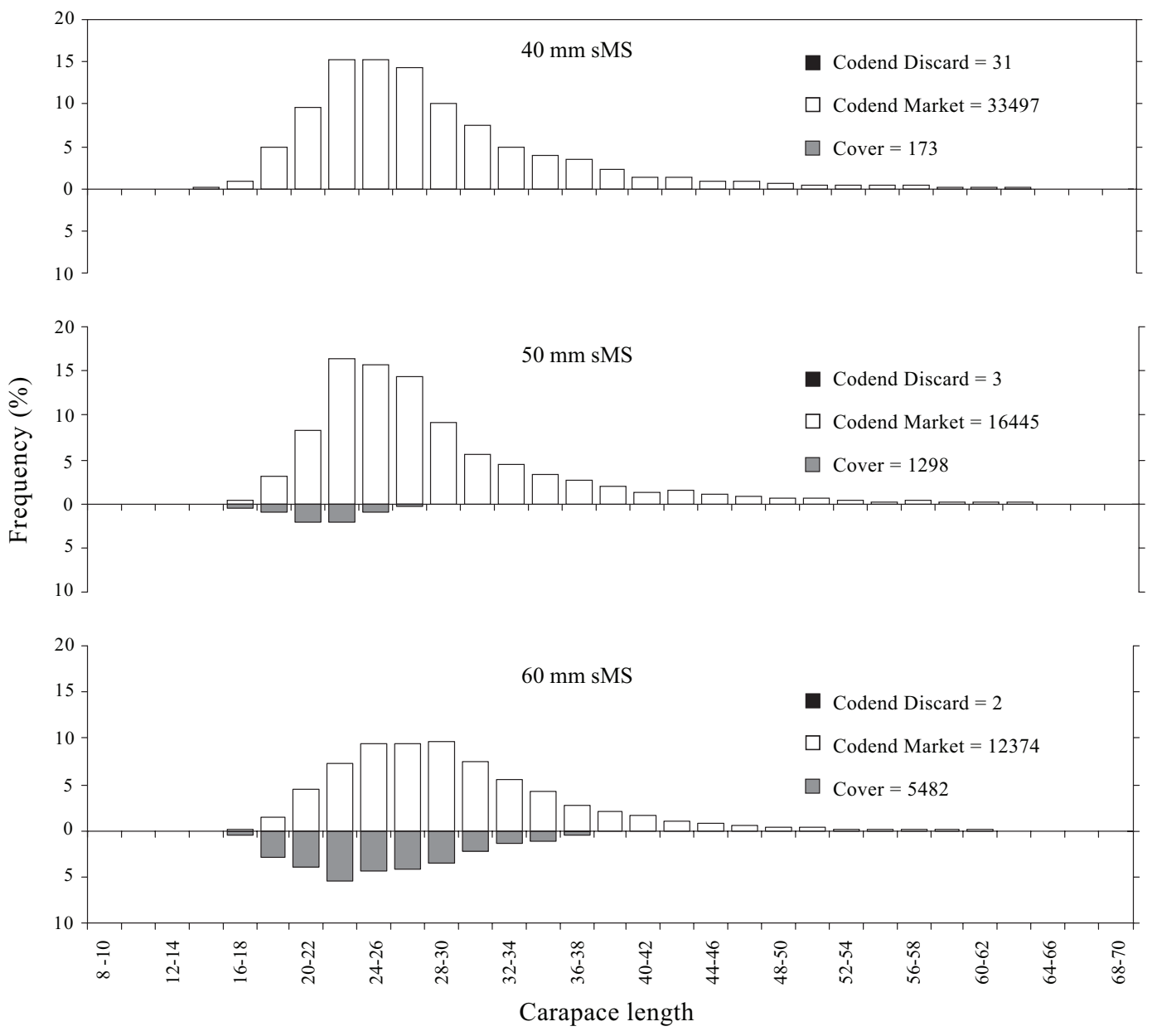

Fig. 8. Length frequency distribution of Aristeus antennatus collected in the codend (40,50 and $60 \mathrm{~mm}$ stretched mesh size, sMS) and in the cover with indication of discarded and marketable fraction. 


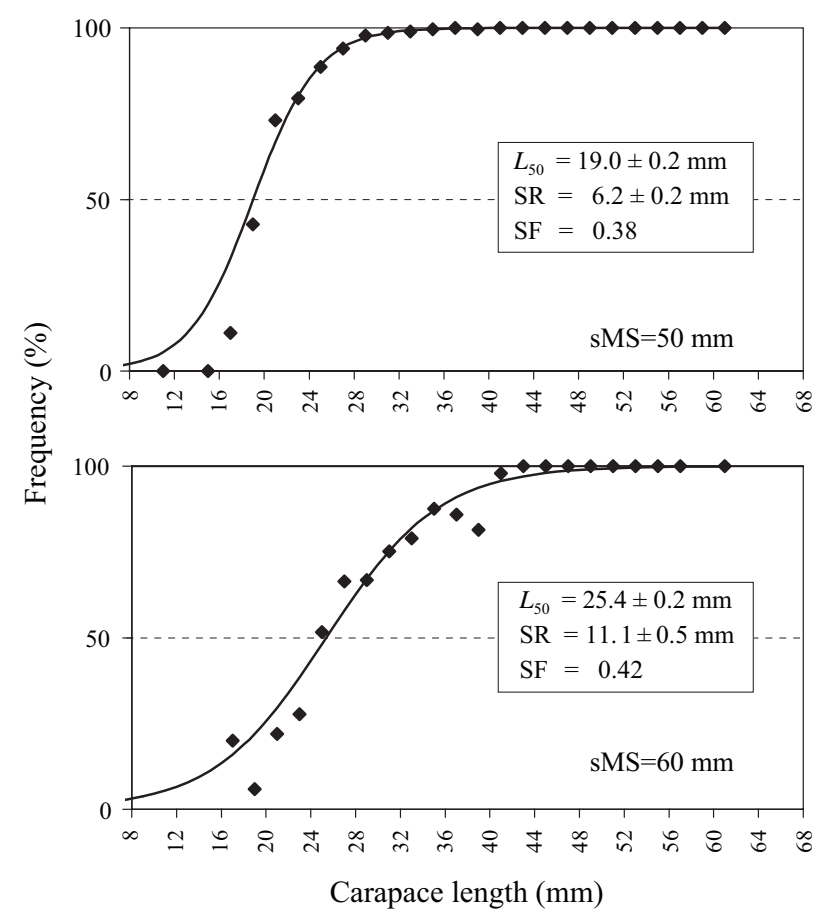

Fig. 9. Estimated selectivity curves for Aristeus antennatus by stretched mesh sizes (sMS) showing the retention size at $50 \%\left(L_{50}\right)$, selection range $(\mathrm{SR})$ and selection factor (SF).

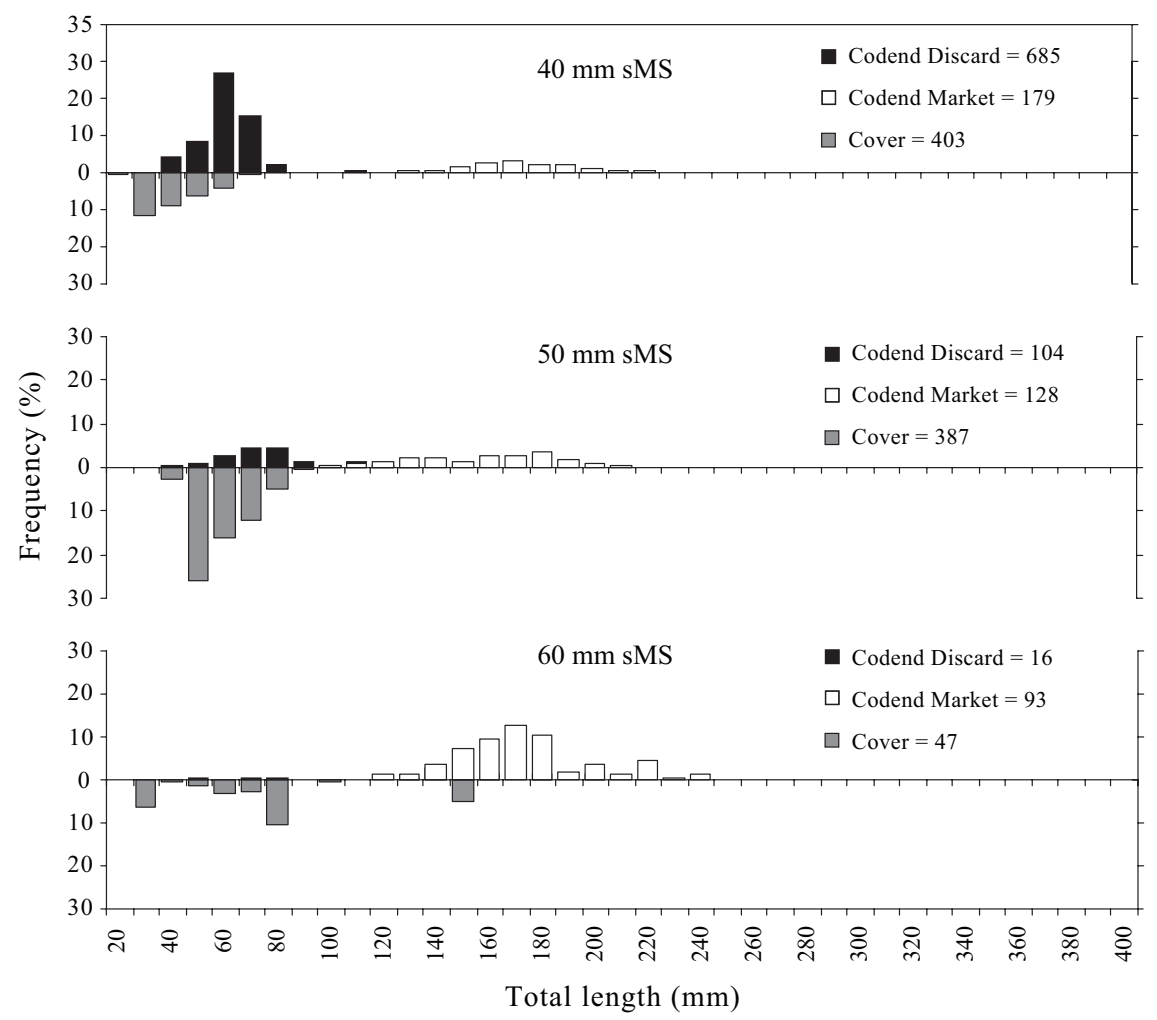

Fig. 10. Length frequency distribution of Helicolenus dactylopterus collected in the codend (40,50 and $60 \mathrm{~mm}$ sMS) and cover with indication of discarded and marketable fraction. 

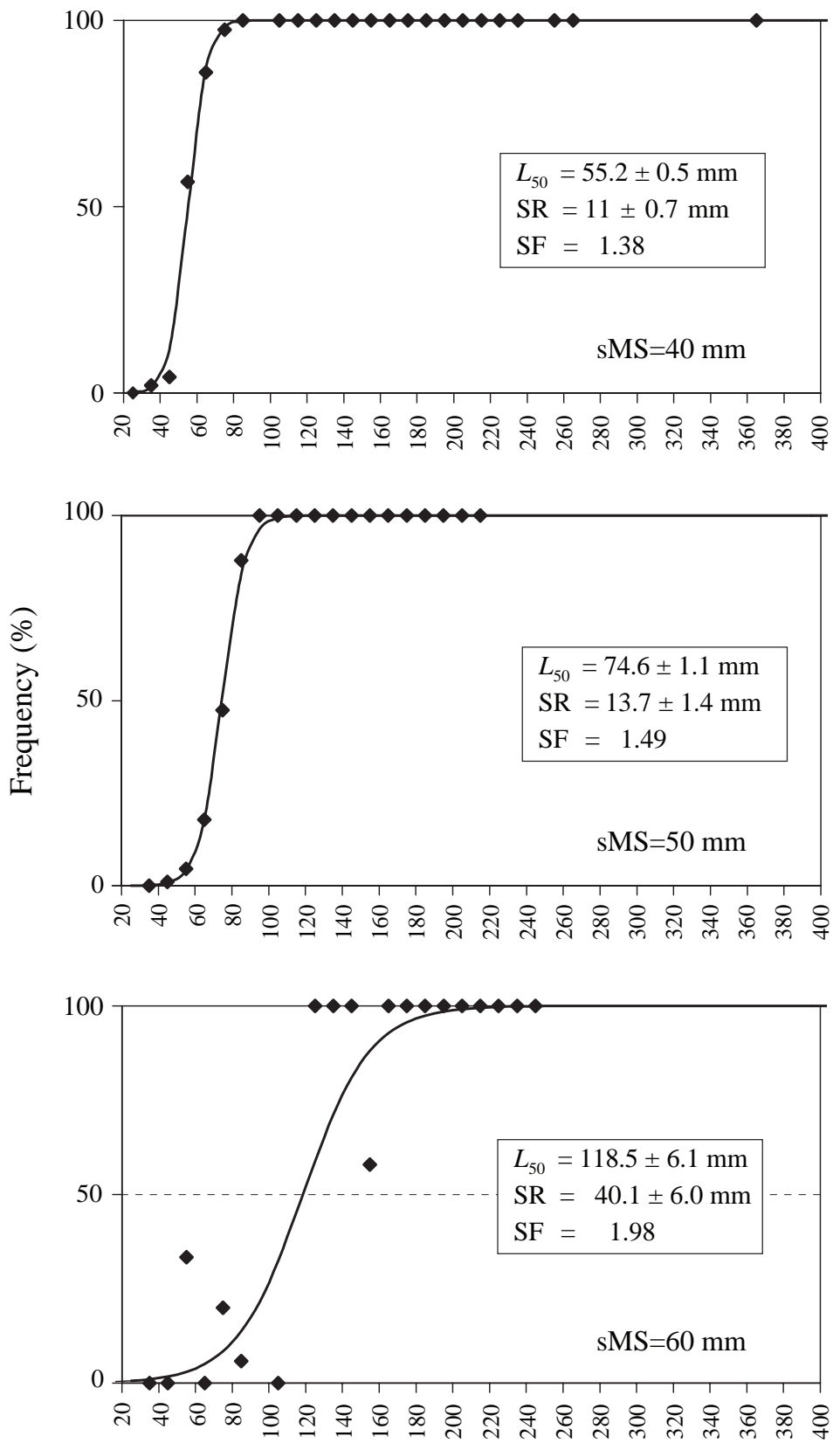

Total length $(\mathrm{mm})$

Fig. 11. Estimated selectivity curves for Helicolenus dactylopterus by stretched mesh sizes (sMS).

Micromesistius poutassou is a demersal species whose recruitment occurs on the continental shelf, so that only larger specimens are captured on the slope (Tursi et al., 1993) Fish smaller than $190 \mathrm{~mm}$ TL were always discarded. Only with the $60 \mathrm{~mm}$ sMS codend did a noticeable proportion of individuals escape into the cover (Fig. 14). However, the available data did not fit any reliable selection curve.

For Caelorhinchus caelorhinchus the fraction of specimens escaping into the cover also increased with mesh size in the codend (Fig. 15). The retention sizes 

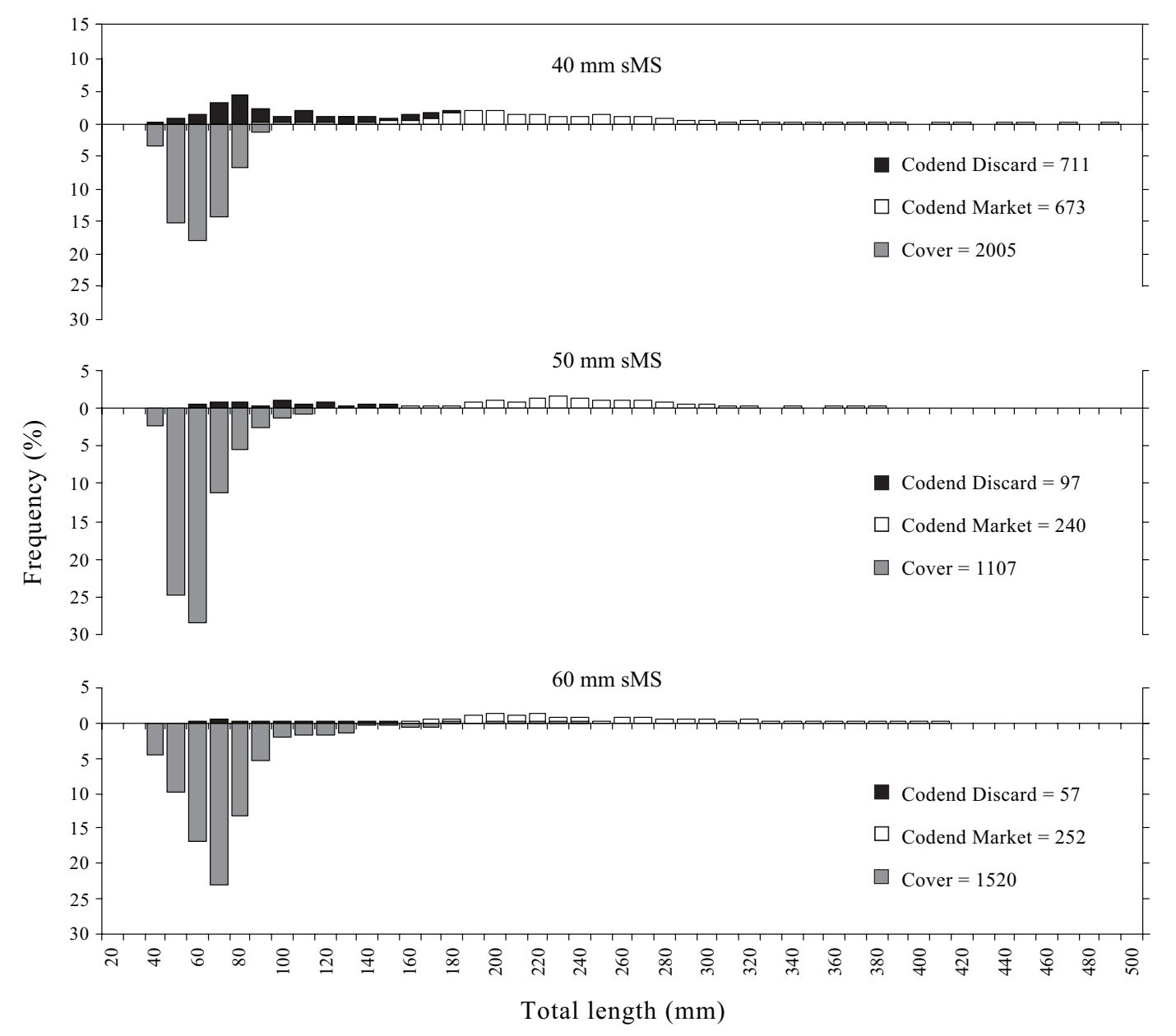

Fig. 12. Length frequency distribution of Phycis blennoides collected in the codend (40,50 and $60 \mathrm{~mm}$ sMS) and cover with indication of discarded and marketable fraction.

at $50 \%$ for the three sMS codends were $24.9 \pm 0.1 \mathrm{~mm}$ PAL, $33.9 \pm 0.4 \mathrm{~mm}$ PAL and $47.4 \pm 0.6 \mathrm{~mm}$ PAL respectively (Fig. 16). Both the selection range and the selection factor computed for the $60 \mathrm{~mm}$ sMS codend were markedly greater than those calculated for 40 and $50 \mathrm{~mm}$.

\section{Discussion}

The discarded catch from the deep-water shrimp fishery in the Ionian Sea constitutes an important fraction of the total catch (20-50\%), as shown in other Mediterranean areas (Carbonell et al., 1998; Moranta et al., 2000; Machias et al., 2001; Ragonese et al., 2001). It is almost exclusively due to unwanted fish species while discards of the target species A. antennatus and A. foliacea and other commercial species were negligible. Although the discard rate varied monthly, no significant differences were seen between the seasons. In contrast, the discard rate increased with total catch and depth as shown in the northeastern Mediterranen (Machias et al., 2001). According to Stergiou et al. (1998), the positive increase in discards with total catch could be due to the decreasing selectivity of codends as they fill and meshes become masked. Moreover, a greater fraction of crushed specimens may occur when the codend is full. The positive increase in discards with depth may be attributed to the greater abundance of unwanted species, such as the macrourid fishes, Hoplostethus mediterraneus and Galeus melastomus, in the study area (Matarrese et al., 1996; D'Onghia et al., 1998b).

According to Ragonese et al. (2001), no substantial differences were seen in the quantitative and qualitative overall performance of the codends used. Differences were only detected in the biomass of the escaped fraction of the catch (both marketable 

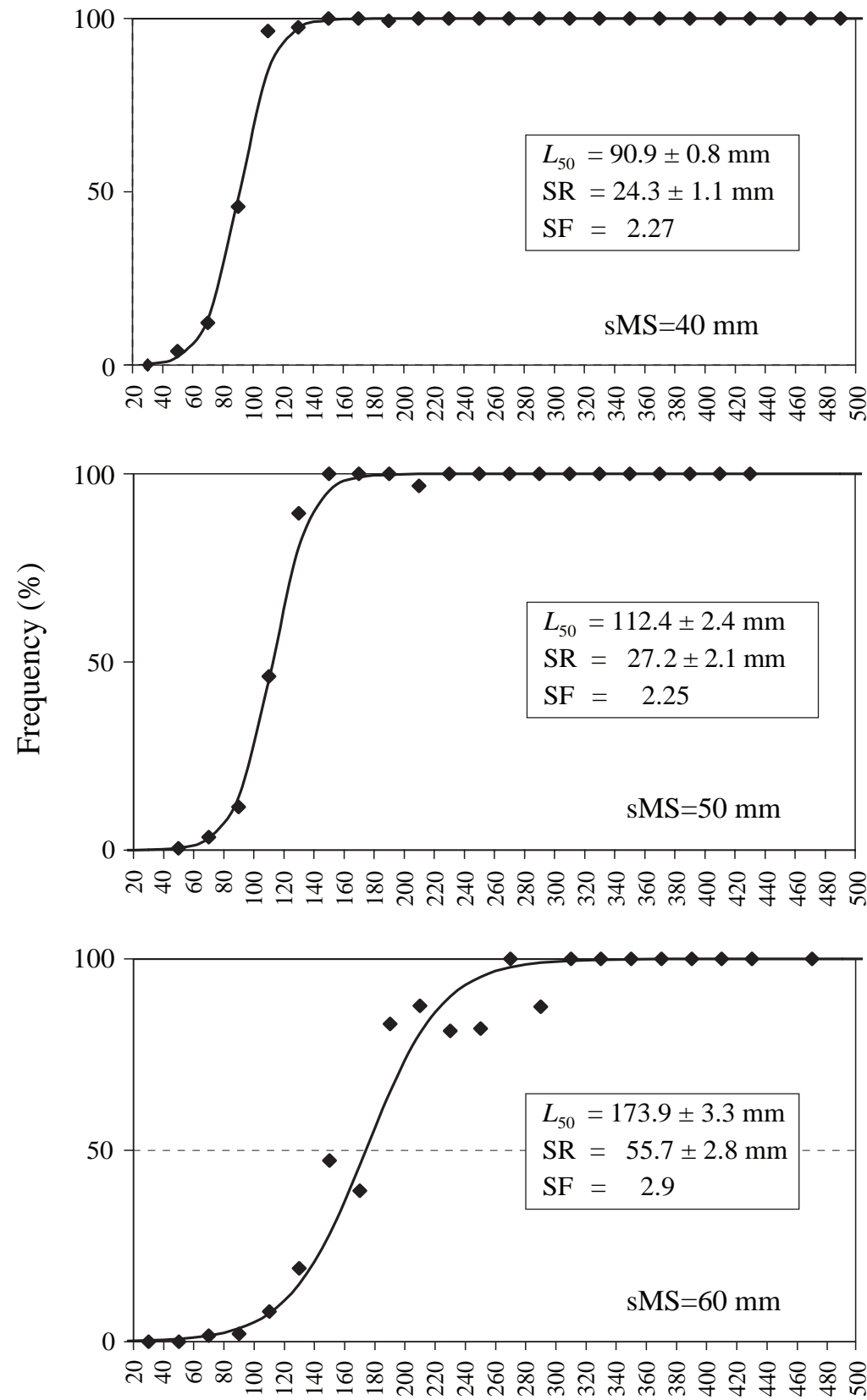

Total length (mm)

Fig. 13. Estimated selectivity curves for Phycis blennoides by stretched mesh sizes ( $\mathrm{sMS}$ ).

and discards) and in the size selectivity. In particular, both the number of small specimens escaping from the meshes and the $50 \%$ retention sizes increased with the mesh size in all examined species. The selection range and the selection factor also generally increased with the mesh size indicating a different selection process between the codends. This could be the consequence of the pooling of data in addition to other factors, which could affect the selection curve (Briggs, 1986). However, the $60 \mathrm{~mm}$ sMS mostly reduces the capture of $A$. antennatus specimens smaller than 30 $\mathrm{mm} \mathrm{CL}$, which have the lowest market value and most of them are generally immature. It avoids almost completely the catch of $H$. dactylopterus and $P$. blennoides juveniles otherwise discarded using the presently used codend (40 $\mathrm{mm} \mathrm{sMS}$ ) and allows a large 


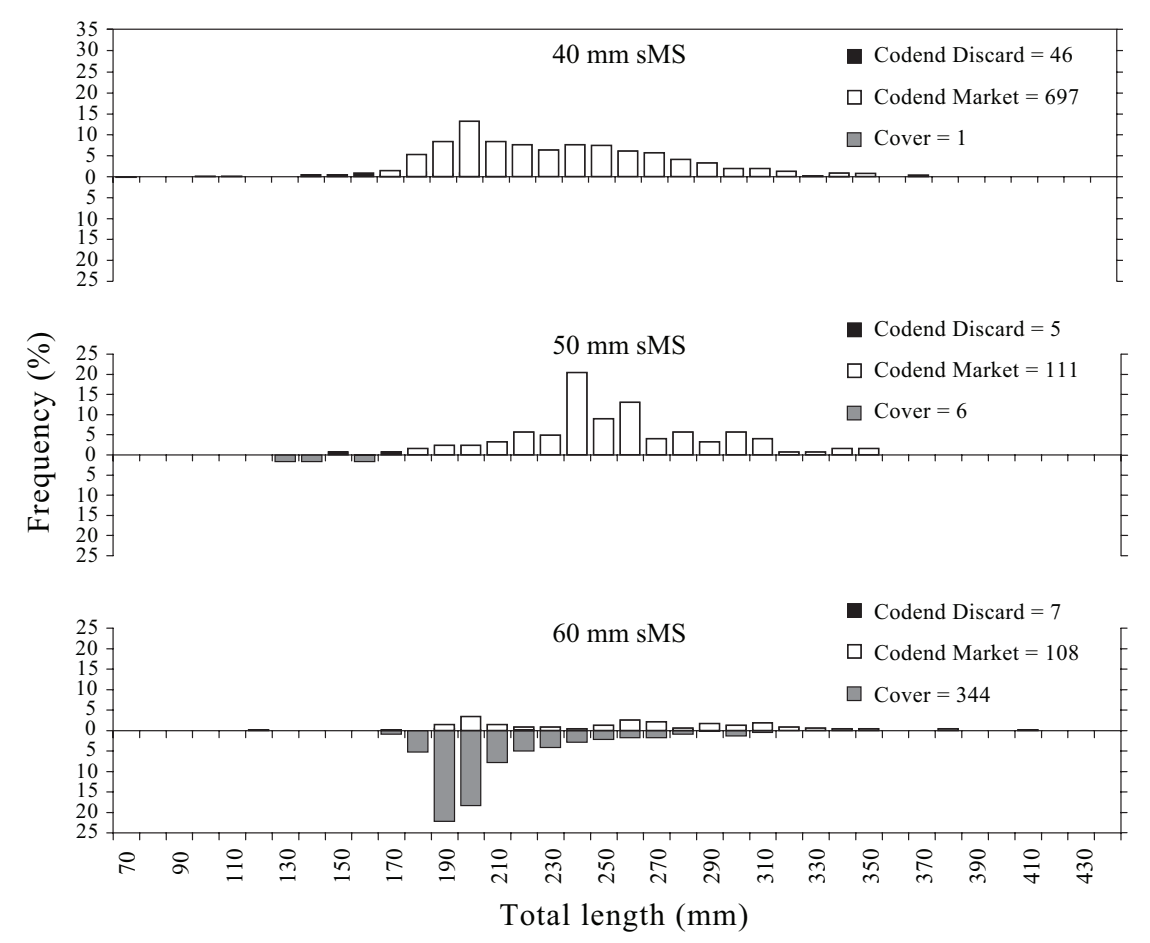

Fig. 14. Length frequency distribution of Micromesistius poutassou collected in the codend (40, 50 and $60 \mathrm{~mm}$ sMS) and cover with indication of discarded and marketable fraction.
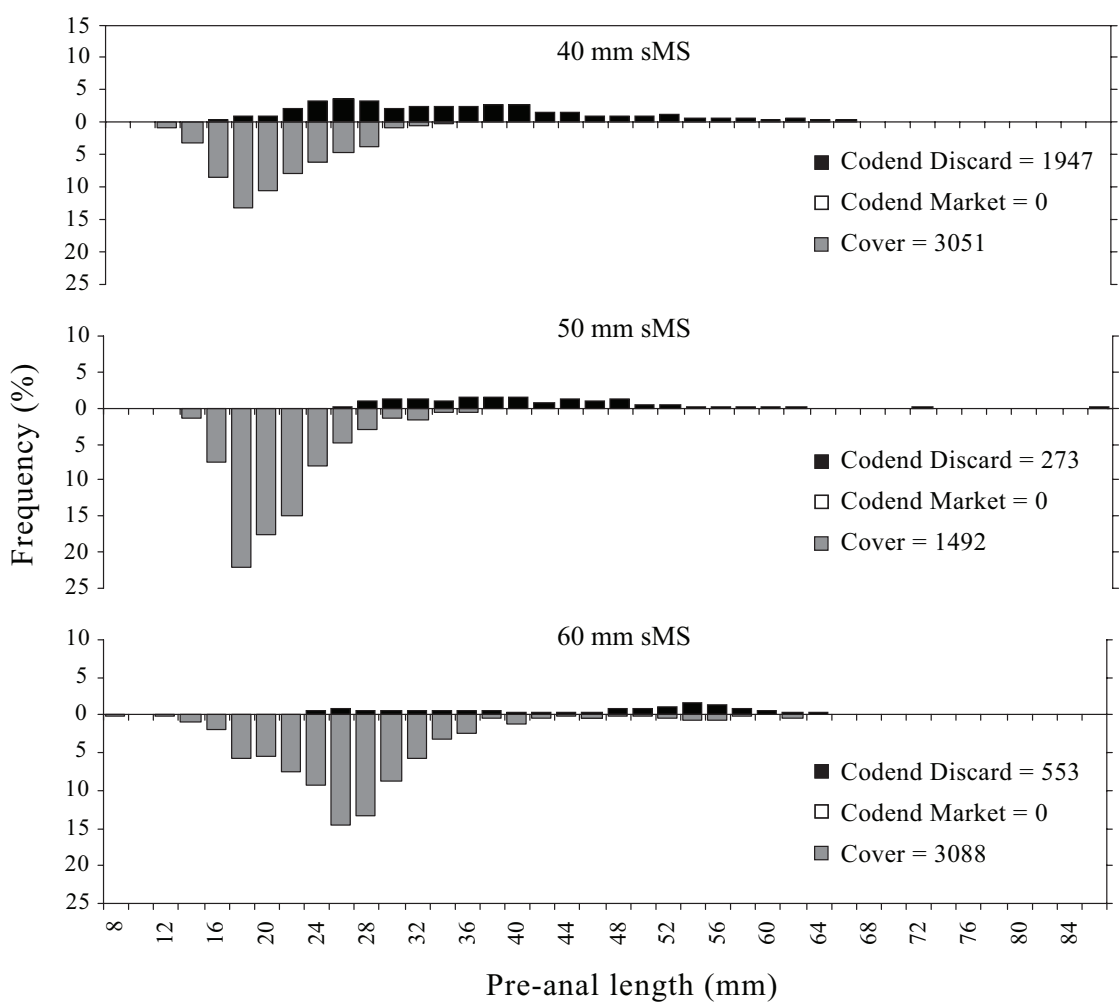

Fig. 15. Length frequency distribution of Caelorhynchus caelorhynchus collected in the codend (40, 50 and $60 \mathrm{~mm}$ sMS) and cover with indication of discarded and marketable fraction. 

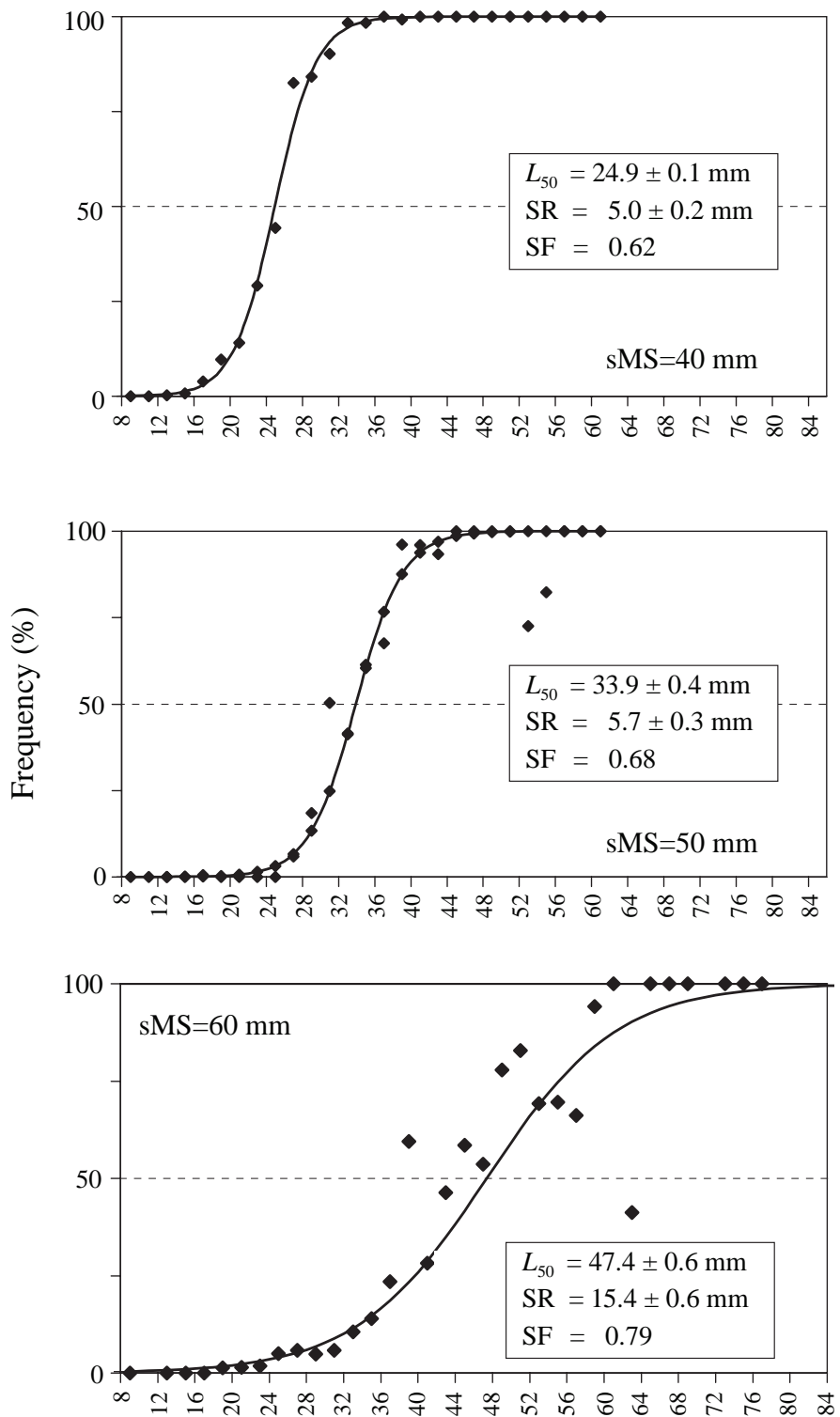

Pre-anal length

Fig. 16. Estimated selectivity curves for Caelorhynchus caelorhynchus by stretched mesh sizes (sMS).

fraction of small specimens of by-catch and unwanted species to escape. Ragonese et al. (1994, 2001) reported that the adoption of a larger mesh size (28 $\mathrm{mm}$ side) reduces the capture of low value or undersize specimens, minimizing the sorting time and improving the catch quality. However, considering that nothing is known about the survival of escaped specimens during deep shrimp trawling, it is not yet possible to quantify the reduction of juvenile mortality or of the impact on the deep-sea living resources.
Several studies have shown that fish escaping from gears are seriously damaged and unable to make a complete recovery (in Chopin and Arimoto, 1995). Individuals would be subjected to capture stress and physical injuries both in the cod-end due to contact with other organisms and debris, and when passing through the mesh. Unfortunately, very little is known about the survival of crustacean species (e.g. Smith and Howell, 1987; Hill and Wassenberg, 1990; Stevens, 1990) and nothing about $A$. antennatus. 
According to Ragonese et al. (1994, 2001), the introduction of a larger mesh size would cause minimal economic loss (due to the very small unit value of small-size specimens which would escape). However, the adoption of such a regulation becomes questionable for those fisheries because, as in this case, they are based on shelf and upper slope multispecies assemblages (Caddy, 1990). In particular, in the study area the trawlers fish over a wide depth range. The same trawlers can fish both on deepwater shrimps (A. foliacea and A. antennatus) on the upper slope, and on the rose shrimp and hake on the shelf edge and upper slope. Depending on sea state or weather conditions and the varying availability of the resources they can also fish in very shallow waters targetting red mullet and other coastal species. Thus, the adoption of a larger mesh than $40 \mathrm{~mm}$ stretched would appear to be feasible as part of the regulation of an almost monospecific fishery targetting deep-water shrimps on the slope, but only after the assessment of its long-term effects on stock levels and catches.

\section{Acknowledgements}

This work was supported by DG XIV of the European Commission as part of the project "Developing deep-water fisheries: data for their assessment and for understanding their interaction with and impact on a fragile environment" (DEEPFISHERIES CT 96-0655).

\section{References}

ALVERSON, D. L., M. H. FREEBERG, S. S. MURASKI, and J. G. POPE. 1994. A global assessment of fisheries by-catch and discards. FAO Fish. Tech. Pap., 339: 233 p.

BRIGGS, R. P. 1986. A general review of mesh selection for Nephrops norvegicus. Fish. Res., 4: 59-73.

CADDY, J. F. 1990. Options for the regulation of Mediterranean demersal fisheries. Nat. Resour. Modeling, 4: 427-475.

CARBONELL, A., P. MARTIN, S. DE RANIERI, and WEDIS team. 1998. Discards of the Western Mediterranean trawl fleet. Rapp. Comm. int. Mer Médit., 35: 392-393.

CHOPIN, F. S., and T. ARIMOTO. 1995. The condition of fish escaping from fishing gears - a review. Fish. Res., 1, 315-327.

D'ONGHIA, G., F. MASTROTOTARO, P. MAIORANO, and M. BASANISI. 1998a. Selettività della rete a strascico utilizzata sui fondi di scarpata $(250-750 \mathrm{~m})$ dello Ionio (Mediterraneo Centrale). Biol. Mar. Medit, 5(2): 437-448.

D'ONGHiA, G., A. TURSi, A., M. BASANisi, and F. MASTROTOTARO. 1997. Commercial trawling, discards and recruitment from a fishery of the northwestern Ionian Sea. Biol. Mar. Medit., 4(1): 291-297.

D'ONGHIA, G., A. TURSI, P. MAIORANO, A. MATARRESE, and M. PANZA. 1998b. Demersal fish assemblages from the bathyal grounds of Ionian Sea (middle-eastern Mediterranean). Ital. J. Zool. Suppl., 65: 287-292.

FIORENTINI, L., G. COSIMI, A. SALA, and V. PALUMBO. 1994. Caratteristiche e prestazioni delle attrezzature a strascico impiegate per la Valutazione delle Risorse Demersali in Italia. Biol. Mar. Medit., 1(2): 115-134.

HILL, B. J., and T. J. WASSENBERG. 1990. Fate of discards from prawn trawlers in Torres Strait. Aust. J. Mar. Fresh. Res., 41: 53-64.

MACHIAS, A., V. VASSILOPOULOU, D. VATSOS, P. BEKAS, A. KALLIANIOTIS, C. PAPACONSTANTINOU, and N. TSIMENIDES. 2001. Bottom trawl discards in the northeastern Mediterranean Sea. Fish. Res., 53: $181-195$.

MATARRESE, A., G. D'ONGHiA, A. TURSi, and M. BASANISI. 1996. New information on the ichthyofauna of the south-eastern Italian coasts (Ionian Sea). Cybium, 20(2): 197-211.

MORANTA, J., E. MASSUTİ, and B. MORALES NIN. 2000. Fish catch composition of the deep-sea decapod crustaceans fisheries in the Balearic Islands (western Mediterranean). Fish. Res., 45: 253-264.

POPE S., A. R. MARGETTS, J. M. HANLEY, and A. F. AKUZ. 1975. Manual of methods for fish stock assessment. Part III. Selectivity of fishing gear. FAO Fish. Tech. Pap., 145: $65 \mathrm{p}$.

RAGONESE, S., M. L. BIANCHINI, L. DI STEFANO, S. CAMPAGNUOLO, and F. BERTOLINO. 1994. Study of the selectivity and assessment of the coefficient of retention of the trawl nets used for red shrimps fishing (Aristaeomorpha foliacea Risso, 1827 and Aristeus antennatus Risso, 1816; Crustacea. Aristeidae) in the Sicilian Channel (Central Mediterranean Sea). Project. MED 92/010, Final report, $300 \mathrm{p}$.

RAGONESE, S., M. ZAGRA, L. DI STEFANO, and M. L. BIANCHINI. 2001. Effect of codend mesh size on the performance of the deep-water bottom trawl used in the red shrimp fishery in the Strait of Sicily (Mediterranean Sea). Hydrobiologia, 449: 279-291.

SMITH, E. M., and P. T. HOWELL. 1987. The effects of bottom trawling on American lobsters Homarus americanus, in Long Island Sound. Fish. Bull. 85(4): 737-744.

SOKAL, R. R., and F. J. ROHLF. 1969. Biometry. W.H. Freeman and Co., San Francisco, 776 p.

SPARRE, P., and S.C. VENEMA. 1998. Introduction to tropical fish stock assessment. Part 1. Manual. FAO Fish. Tech. Pap., 306.1, Rev. 2, 407 p.

STERGIOU, K. I., A. ECONOMOU, C. PAPACONSTANTINOU, N. TSIMENIDES, and S. KAVADAS. 1998. Estimates of discard in the Hellenic commercial trawl fishery. Rapp. Comm. int. Mer, 35: 490-491.

STERGIOU, K. I., C.-Y. POLITOU, E. D. CHRISTOU, and G. PETRAKIS. 1997. Selectivity experiments in the NE Mediterranean: the effect of trawl codend mesh size on the species diversity and discard. ICES J. Mar. Sci., 54: 774-786.

STEVENS, B. G. 1990. Survival of King and Tanner crabs captured by commercial sole trawlers. Fish. Bull. 88: 731-744. 
TURSI, A., L. SION, P. MAIORANO, and M. PANZA. 1993. Le nurseries di Micromesistius poutassou (Risso, 1826) nel Mar Ionio. Biol. Mar., Suppl., 1: 377-378.

TURSI, A., A. MATARRESE, G. D'ONGHIA, P. MAIORANO, and M. PANZA. 1998. Sintesi delle ricerche sulle risorse demersali del Mar Ionio (da Capo d'Otranto a Capo
Passero) realizzate nel periodo 1985-1997. Biol. Mar. Medit., 5(3): 120-129.

WILEMAN, D. A., R. S. T. FERRO, R. FONTEYNE, and R. B. MILLAR (eds.). 1996. Manual of Methods of Measuring the Selectivity of Towed Fishing Gears. ICES Coop. Res. Rep., No. 215, 126 p. 
